\title{
Assessment of Foreign Material Load in the Management of Faecal Sludge in the Greater Accra Region of Ghana
}

\author{
Issahaku Ahmed ${ }^{1,}$, Ama Mbeaba Quarshie ${ }^{2}$, Dennis Ofori-Amanfo ${ }^{1}$, Florence Cobbold ${ }^{1}$, \\ Eric Simon Amofa-Sarkodie ${ }^{1}$, Esi Awuah, ${ }^{3,}$ \\ ${ }^{1}$ Sewerage Systems Ghana Ltd., Accra, Ghana \\ ${ }^{2}$ Department of Basic \& Applied Biology, University of Energy and Natural Resources, Sunyani, Ghana \\ ${ }^{3}$ Department of Civil Engineering, Kwame Nkrumah University of Science and Technology, Kumasi, Ghana \\ Email address: \\ eagleskertoozer@yahoo.co.uk (I. Ahmed), amambeaba@yahoo.com (A. M. Quarshie), oblon13@hotmail.com (D. Ofori-Amanfo), \\ fcobbold@hotmail.com (F. Cobbold), trustsark@gmail.com (E. S. Amofa-Sarkodie), esiawuahrt@gmail.com (E. Awuah) \\ ${ }^{*}$ Corresponding author
}

\section{To cite this article:}

Issahaku Ahmed, Ama Mbeaba Quarshie, Dennis Ofori-Amanfo, Florence Cobbold, Eric Simon Amofa-Sarkodie, Esi Awuah. Assessment of Foreign Material Load in the Management of Faecal Sludge in the Greater Accra Region of Ghana. International Journal of Energy and Environmental Science. Vol. 3, No. 1, 2018, pp. 27-36. doi: 10.11648/j.ijees.20180301.13

Received: January 29, 2018; Accepted: February 11, 2018; Published: March 6, 2018

\begin{abstract}
Faecal sludge management has been a burden for most waste managers particularly in developing countries; yet a sure way of preventing the continuous disposal of this waste into drains, bushes water bodies and the environs in general has been by treatment. The introduction of a new treatment plant with the UASB technology in the management process of faecal sludge has been much welcomed as an improved technology for solving the treatment problems of the waste; but this technology is not without some challenges. It has no design criteria for the treatment of other wastes that it screens from faecal sludge. This paper assessed the foreign material load in faecal sludge dislodged at the treatment plant at the Lavender hill a suburb of the Greater Accra region of Ghana. The foreign materials in the faecal sludge were categorized into their material composition or items that were relatively easy to recognized. The characteristic components were Textile/Fabric, Condoms, Gravels, Metal, Glass, Sanitary pads, Rubber/Plastics and Others' (cotton wool, mobile phones, broom sticks, paper wrappers, cartons, wallets, ID cards, money, feotus). The faecal sludge of Greater Accra region of Ghana contains about $0.24 \mathrm{~kg}$ of foreign materials per cubic metre of the faecal sludge. Of this composition, the highest contribution was seen to have come from plastics contributing about $36.80 \%$. Sanitary pads, textiles, 'others' category, condoms, stones, metals and glasses respectively contributing $29.89 \%, 18.55 \%, 7.47 \%, 3.74 \%, 2.52 \%, 0.06 \%$ and $0.16 \%$. The order of the load of the foreign materials were seen to be in the order of Plastics/Rubbers $>$ Sanitary pads $>$ Textiles/Fabrics $>$ Others $>$ Condoms $>$ Gravels $>$ Glass $>$ Metals. These wastes pose mechanical and technical challenges to the treatment plant. Inasmuch as responsible environmental behavior through public sensitization on proper use of pit latrines in particular and the need for their redesign to make them almost impossible for use as dumping pits for other wastes were recommended, the utilization of some of these foreign materials that have the potential to be reused like the money, memory chips or mobile phones could potentially be a source of spread for disease like cholera and diarrhea as the FS contains a lot of pathogenic bacteria.
\end{abstract}

Keywords: Faecal Sludge, Latrines, UASB Technology, Characterization, Foreign Material Load

\section{Introduction}

Sanitation management is a herculean task for municipal waste managers so far as environmental health is concerned. The disposal of refuse and faecal waste into drains, bushes and other sectors of the environment are on the rise and has led to the worsening of sanitation situations in most parts of the world especially in developing countries. UNICEF and the World Health Organization [1] reported that the world is far from meeting the Millennium Development Goal (MDG) target on sanitation and that as much as 2.5 billion people currently cannot access improved sanitation facilities. In their 2012 report however, they indicated that the past decade has seen some improvement in the sanitation access worldwide 
unlike the sub-Saharan Africa, where $70 \%$ of the populace still do not have access to sanitation. [2].

Sewerage systems such as septic tanks and latrines are presently the most affordable solutions to the improvement of universal sanitation situation [3]. About 2.4 billion people in the world, constituting one-third of the total world population still do not have access to sanitation facilities like latrine or sewerage system and 946 million people of this number practice open defecation (Unicef, Uni, \& Noorani, 2016; UNICEF-GHANA, 2015) An estimated number of about 1.5 billion people still use sewerage systems without treatment, while 2.1 billion of residents in urban areas use enhanced sanitation facilities though they do not safely dispose off their human waste. The GIWA Regional Assessment of 2006 report for Colombia, Venezuela, Central America and Mexico [4], also indicated that the sea along the Colombian Caribbean coast receives as much as $472,653 \mathrm{~m}^{3}$ of untreated sewage in a day, whilst back in the year 2000, Africa recorded less than $1 \%$ of their urban wastewater treated before disposal [3]. Sanitation provision should therefore be a civic responsibility and must be done without restrictions. The design of these pit latrines allows them to also be used by some community dwellers as solid waste disposal points and this has resulted in the presence of non-faecal matter in the faecal sludge. Research work by a South African group in the area of pollution indicates that faecal sludge is about $85 \%$ of pit content and the remaining $15 \%$ being solid waste. The solid waste constitutes paper, textile and feminine waste with overall constitution of $7-8 \%, 1-2 \%$, and $1 \%$ [15]. This worrisome picture makes the access to sanitation a global priority.

In Ghana the upsurge of population coupled with inadequate facilities to commensurate with the growth has led to a deteriorating sanitation situation especially in its major capital, Accra. Pit latrines are the most popular means of providing an alternative place of convenience for many municipal areas. Resources allocated for the management of wastewater to ensure that basic sanitation needs are met; are woefully inadequate and this is mainly due to the lack of political will [5]. This has led to vicinities of some household being used as sites for dumping and burying of manually emptied faecal sludge. Water bodies and open fields are also sometimes compelled to function as containments for mechanically emptied sludge as well as the use of sludge for fertilizer or aquaculture in its untreated state [6]. The work of Doku [7] indicated that high percentage of faecal sludge collected by vacuum tankers from cities and towns in Ghana were disposed on land and water bodies. Recent research in Ghana has indicated that wastewater and faecal sludge treatment facilities that are in existence are generally sewerage systems and this low coverage. [8]; and even these few facilities, majority of them are in a deplorable state. The work of Brook [9] has indicated that those facilities that are in deplorable states are normally used by people as dumping sites for non-faecal materials.

It has been reported that, about $30,000 \mathrm{~m}^{3}$ of faecal sludge collected from Accra in the year 2006 were discharged in waste stabilization ponds at Teshie, a suburb of Accra, but these ponds were deemed not to be working efficiently [1012]. Technologies like the oxidation ponds, facultative ponds and storage pond systems have existed in the country for decades. In a related study conducted in Ghana and published in 2013 [13], it was established that the Kumasi Metropolitan Assembly employed the utility of faecal sludge treatment technologies such as the maturation ponds, facultative ponds and anaerobic ponds. The introduction of new treatment technology such as the Upflow Anaerobic Sludge Blanket (UASB) system which is currently used at the new Lavender hill faecal treatment plant, the Mudor and the Kotoku waste water treatment plants among others in the Greater Accra Region requires that the solid waste (foreign materials) load be assessed. The UASB plant was designed to treat sewage and some industrial wastewater. It has no design criteria for the treatment of faecal sludge [7]. Its loading rate is also restricted to either organic or hydraulic load depending on the nature of wastewater to be treated. This could mean that the application of the UASB system in the management of faecal sludge in our region would be very difficult if the foreign material load is not well studied and characterized to inform the screening process of the faecal sludge prior to the UASB utilization.

Almost all research works on the characterization of faecal sludge worldwide is replete with only the physico-chemical properties to the neglect of other foreign materials that have significant effect on the treatment process deployed for its management, this was highlighted in the works of Strande [14]. Research has also indicated that solid waste in faecal sludge can cause a lot of problems to the extent of reducing the quality of treatment $[7,14]$. The quality of the treatment depends on the efficiency of screening by the plant.

The justification for this study is to influence the choice of faecal sludge treatment technologies and to inform design criteria and choice of mechanical screening applications required for the handling of foreign material load prior to treatment. It focuses on the assessment of the characteristics of foreign materials screened by plant. It will give first hand information on the foreign material load and its characteristics in faecal sludge in the Greater Accra Region of Ghana.

\section{Materials and Methods}

\subsection{Study Area}

The study was conducted at the Accra metropolitan area of the Greater Accra region of Ghana; It is bounded at the north by Ga East and the Adenta Municipal Authorities, the south by the Sea (Gulf of Guinea), the East by the Ledzokuku Krowor Municipality and the west by the Ga West, Ga Central and Ga south. The site is designated as a sanitary site by the Accra Metropolitan Assembly and is popularly referred to as the Lavender Hill Faecal Treatment plant. It is the only faecal treatment plant in the region that uses the new technology-UASB and also receives a high number of 
dislodge (numbering about 200 cesspit trucks daily) of sewage from cesspit trucks for treatment among the others. Cesspit trucks from all municipalities of the Greater Accra region and some part of Eastern and Central regions of the country dislodge sewage at the treatment plant. This and other reasons explain why the plant was purposively selected for the study.

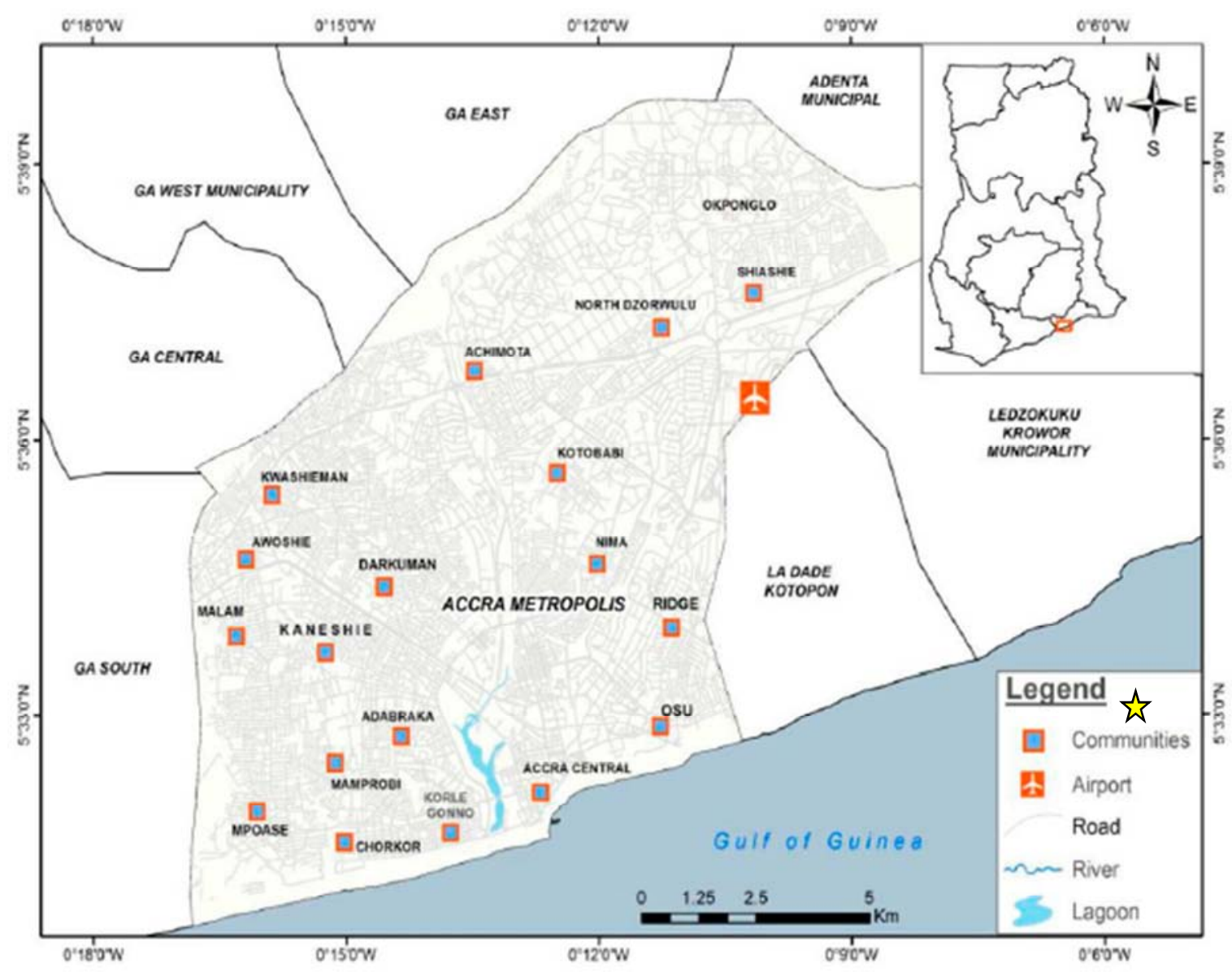

Figure 1. Map of Accra Metropolis.

\subsection{Study Design}

This work observed health and safety precautions which preceded direct screening, sorting and weighing of foreign material load in faecal sludge into their respective material compositions. Analyses were made based on their weights and percentages.

\subsection{Equipment}

Equipment used for the study included, a $300 \mathrm{~kg}$ capacity weighing scale (Avery Weight- Tronix AWB120), 240 - liter bins, sorting containers, rakes, spade and digital mobile phone for taking pictures.

\subsection{Methodology}

\subsubsection{Health and Safety Considerations}

Four personnel were selected from the plant attendants of the faecal treatment plant and were trained by the quality control supervisor on the high risk associated with the handling of foreign materials in faecal sludge. The personnel were also given lessons on safety guidelines such as the use of protective devices and the observance of safety procedure as well as waste sorting protocols. They were each provided with personal protection equipment such as a pair of gloves, safety boots, overall, disposable nose masks, disinfectants and a personal emergency response number for prompt response in case of emergency. They were then guided on their first sorting event to ensure that their activities will assist in achieving the objective of the study.

\subsubsection{Sampling Design}

Sampling was done daily within 1 hour of the peak periods of operation (9.00am to $11.00 \mathrm{am})$ during which a simple random sampling technique was employed to select the number of trucks to be used for the study. With this technique, the faecal sludge content of the trucks which could desludge into a reservoir at the receiving bay within the one hour duration for the day formed the sample for the study. The influent was then allowed to undergo primary screening by a $30 \mathrm{~mm}$ screen before a secondary screening where foreign materials larger than $6 \mathrm{~mm}$ were also screened. The study period lasted for Seven weeks.

All screened materials were then transported in litter bins 
to an open space and allowed to dry to minimum moisture content. After drying, the materials were then sorted according to their respective material into containers composition using rake and spade. A weighing scale of $300 \mathrm{~kg}$ capacity was used to weigh the sorted materials and recorded on a data sheet.

\subsubsection{Classification of the Foreign Materials}

Material composition of solid waste classification exist to guide the classification of many survey on waste management studies; in contrast to faecal sludge management study such as this, fewer categories may be required [14]. However foreign materials in the faecal sludge were categorized into their material composition or items that were relatively easy to recognized. The number of categories was reduced to minimize the contact time of personnel with FS and level of effort involve in executing the research. The classification of foreign material in FS employed after a critical assessment of FS composition at the treatment plant included;

1) Wood

2) Textile/Fabric (underwear's, shirts, jeans, cloth, rugs, etc)

3) Condoms

4) Gravels

5) Metal

6) Glass

7) Sanitary pads

8) Rubber/Plastics (plastic bottle, toys, slippers, tooth brushes, sachet water wrappers, black polythene, sponges, spray covers)

'Others' (cotton wool, mobile phones, broom sticks, paper wrappers, cartons, wallets, ID cards, money, feotus)

\section{Results}

Table 1. Comprehensive Data on Foreign Materials Load in Faecal Matter.

\begin{tabular}{|c|c|c|c|c|c|c|c|c|c|c|}
\hline \multirow{2}{*}{ Composition } & \multicolumn{10}{|l|}{ DAYS } \\
\hline & 1 & 2 & 3 & 4 & 5 & 6 & 7 & 8 & 9 & 10 \\
\hline Plastic/rubber & 28.65 & 27.65 & 41.3 & 53.1 & 22.4 & 22.35 & 29.1 & 19.45 & 37.6 & 37.2 \\
\hline Condoms & 0.56 & 5.8 & 0.7 & 0.80 & 0.4 & 11.05 & 1.1 & 0.35 & 0.45 & 0.20 \\
\hline Textiles & 13.30 & 16.70 & 14.35 & 10.6 & 16.7 & 19.45 & 15.3 & 15.4 & 13.2 & 14.6 \\
\hline Ceramic/glass & 0.82 & & 0.05 & 0.05 & 0.00 & 0.00 & 0.00 & 0.00 & 0.00 & 0.05 \\
\hline Gravels & 2.70 & 1.55 & 1.95 & 5.6 & 4.95 & 0.05 & 0.00 & 0.25 & 0.00 & 0.10 \\
\hline Metals & & & 0.2 & 0.05 & 0.01 & 0.00 & 0.00 & 0.00 & 0.05 & 0.00 \\
\hline Sanitary pad & 22.4 & 16.56 & 3.68 & 17.2 & 54.76 & 20.92 & 14.08 & 19.60 & 32.84 & 10.08 \\
\hline Others & 5.6 & 4.14 & 0.92 & 4.3 & 13.69 & 5.23 & 3.52 & 4.90 & 8.21 & 2.52 \\
\hline Total Weight $(\mathrm{Kg}) /$ day & 74.28 & 73.44 & 64.1 & 93.35 & 113.36 & 79.2 & 63.7 & 60.5 & 92.65 & 65.45 \\
\hline Percentage $(\%) /$ day & 5 & 5 & 4 & 6 & 8 & 5 & 4 & 4 & 6 & 5 \\
\hline Total No. of trucks/day & 35 & 35 & 32 & 38 & 49 & 36 & 30 & 31 & 41 & 34 \\
\hline Sampled vol/day $\left(\mathrm{m}^{3}\right)$ & 315 & 315 & 288 & 342 & 441 & 324 & 270 & 279 & 369 & 306 \\
\hline
\end{tabular}

Table 1. Continue.

\begin{tabular}{|c|c|c|c|c|c|c|c|c|c|c|}
\hline \multirow{2}{*}{ Composition } & \multicolumn{10}{|l|}{ DAYS } \\
\hline & 11 & 12 & 13 & 14 & 15 & 16 & 17 & 18 & Total & $\%$ \\
\hline Plastic/rubber & 19.95 & 27.3 & 19.10 & 21.55 & 36.77 & 29.00 & 31.5 & 27.57 & 531.54 & 36.80 \\
\hline Condoms & 0.25 & 0.25 & 0.70 & 9.50 & 6.0 & 0.45 & 10.20 & 5.25 & 54.01 & 3.74 \\
\hline Textiles & 8.95 & 9.1 & 8.05 & 15.77 & 15.0 & 20.10 & 26.50 & 14.89 & 267.96 & 18.55 \\
\hline Ceramic/glass & 0.00 & 0.01 & 0.00 & 0.1 & 0.51 & 0.0 & 0.25 & 0.54 & 2.33 & 0.16 \\
\hline Gravels & 0.00 & 0.05 & 0.00 & 2.50 & 8.45 & 0.67 & 4.00 & 3.52 & 36.34 & 2.52 \\
\hline Metals & 0.00 & 0.00 & 0.00 & 0.00 & 0.00 & 0.50 & 0.04 & 0.00 & 0.85 & 0.06 \\
\hline Sanitary pad & 12.44 & 7.40 & 12.92 & 54 & 48.20 & 16.72 & 34.40 & 33.52 & 431.72 & 29.89 \\
\hline Others & 3.11 & 1.85 & 3.23 & 13.5 & 12.05 & 4.18 & 8.60 & 8.38 & 107.92 & 7.47 \\
\hline Total Weight $(\mathrm{Kg}) /$ day & 45.15 & 46.71 & 44.4 & 117.37 & 127.26 & 72.6 & 116.1 & 94.29 & 1444.32 & 100 \\
\hline Percentage $(\%) /$ day & 3 & 3 & 3 & 8 & 9 & 5 & 8 & 7 & 100 & \\
\hline Total No. of trucks/day & 28 & 25 & 22 & 49 & 55 & 39 & 48 & 40 & 667 & \\
\hline Sampled vol/day $\left(\mathrm{m}^{3}\right)$ & 252 & 225 & 198 & 441 & 495 & 351 & 432 & 360 & 6003 & \\
\hline
\end{tabular}

Table 2. Comprehensive Data on Foreign Materials Load in Faecal Matter from both public and private toilet facilities.

\begin{tabular}{|c|c|c|c|c|c|c|c|c|c|c|c|c|}
\hline Characterisation & public & Private & public & private & public & private & public & private & public & Private & public & private \\
\hline unit & Kg/day & & & & & & & & & & & \\
\hline Composition & Day 1 & & Day 2 & & Day 3 & & Day 4 & & Day 5 & & Day 6 & \\
\hline Plastic/rubber & 5.04 & 4.70 & 13.31 & 1.95 & 6.02 & 5.25 & 6.01 & 4.01 & 15.05 & 9.56 & 5.98 & 3.99 \\
\hline Condoms & 0.006 & 0.006 & 0.03 & 0.009 & 0.08 & 0.03 & 0.14 & 0.06 & 0.03 & 0.04 & 0.006 & 0.00 \\
\hline Textiles & 5.20 & 3.71 & 8.69 & 3.80 & 4.32 & 2.30 & 5.98 & 3.06 & 8.92 & 5.25 & 4.98 & 3.00 \\
\hline Ceramic/glass & 0.00 & 0.00 & 0.01 & 0.00 & 0.02 & 0.00 & 0.05 & 0.00 & 0.05 & 0.00 & 0.85 & 0.00 \\
\hline
\end{tabular}




\begin{tabular}{|c|c|c|c|c|c|c|c|c|c|c|c|c|}
\hline Characterisation & public & Private & public & private & public & private & public & private & public & Private & public & private \\
\hline unit & $\mathrm{Kg} /$ day & & & & & & & & & & & \\
\hline Composition & Day 1 & & Day 2 & & Day 3 & & Day 4 & & Day 5 & & Day 6 & \\
\hline Gravels & 1.25 & 0.02 & 2.01 & 0.25 & 1.32 & 0.36 & 0.58 & 0.05 & 2.08 & 0.24 & 1.61 & 0.01 \\
\hline Metals & 0.04 & 0.00 & 0.00 & 0.01 & 0.08 & 0.03 & 0.05 & 0.00 & 0.15 & 0.00 & 0.00 & 0.001 \\
\hline Wood & 0.14 & 0.10 & 0.00 & 0.00 & 0.16 & 0.00 & 0.04 & 0.00 & 0.58 & 0.00 & 0.89 & 0.00 \\
\hline Sanitary pad & 5.32 & 4.30 & 11.31 & 2.70 & 6.25 & 4.28 & 15.98 & 5.69 & 6.50 & 3.95 & 10.32 & 4.55 \\
\hline others & 6.72 & 0.85 & 9.51 & 1.80 & 5.83 & 1.02 & 8.90 & 3.51 & 5.01 & 1.98 & 8.00 & 3.62 \\
\hline Total Weight (Kg)/day & 23.72 & 13.69 & 44.87 & 10.52 & 24.08 & 13.27 & 37.73 & 16.38 & 38.37 & 21.02 & 32.64 & 15.17 \\
\hline Percentage $(\%) /$ day & 4.54 & 2.62 & 8.59 & 2.01 & 4.61 & 2.54 & 7.22 & 3.13 & 7.34 & 4.02 & 6.24 & 2.90 \\
\hline Total No. of trucks/day & 15 & 15 & 15 & 15 & 15 & 15 & 15 & 15 & 15 & 15 & 15 & 15 \\
\hline Sampled vol/day $\left(\mathrm{m}^{3}\right)$ & 135 & 135 & 135 & 135 & 135 & 135 & 135 & 135 & 135 & 135 & 135 & 135 \\
\hline
\end{tabular}

Table 2. Continue.

\begin{tabular}{|c|c|c|c|c|c|c|c|c|c|c|}
\hline Characterisation & public & private & public & private & public & private & public & private & & \\
\hline unit & Kg/day & & & & & & & & & \\
\hline Composition & Day 7 & & Day 8 & & Day 9 & & Day 10 & & Total & $\%$ \\
\hline Plastic/rubber & 19.08 & 9.65 & 6.28 & 5.88 & 14.00 & 10.04 & 13.68 & 7.04 & 166.52 & 31.86 \\
\hline Condoms & 0.15 & 0.003 & 0.30 & 0.00 & 0.26 & 0.006 & 0.22 & 0.006 & 1.38 & 0.26 \\
\hline Textiles & 9.01 & 5.10 & 4.20 & 3.21 & 9.41 & 5.80 & 8.55 & 3.77 & 108.26 & 20.72 \\
\hline Ceramic/glass & 0.05 & 0.001 & 0.00 & 0.00 & 0.45 & 0.00 & 0.06 & 0.00 & 1.54 & 0.29 \\
\hline Gravels & 0.05 & 0.00 & 0.20 & 0.00 & 1.25 & 0.12 & 0.00 & 0.00 & 11.4 & 2.18 \\
\hline Metals & 0.08 & 0.00 & 0.01 & 0.02 & 0.21 & 0.00 & 0.30 & 0.01 & 0.99 & 0.19 \\
\hline Wood & 0.00 & 0.001 & 0.10 & 0.00 & 0.16 & 0.00 & 0.00 & 0.00 & 2.17 & 0.42 \\
\hline Sanitary pad & 14.01 & 5.11 & 6.58 & 7.21 & 8.80 & 3.21 & 5.30 & 4.00 & 130.07 & 24.89 \\
\hline others & 7.26 & 3.99 & 5.88 & 2.32 & 6.98 & 2.32 & 10.67 & 4.09 & 100.26 & 19.19 \\
\hline Total Weight $(\mathrm{Kg}) /$ day & 49.69 & 23.86 & 23.55 & 18.64 & 41.52 & 21.50 & 33.48 & 18.92 & 522.60 & \\
\hline Percentage $(\%) /$ day & 9.51 & 4.56 & 4.51 & 3.57 & 7.94 & 4.11 & 6.41 & 3.62 & 100 & \\
\hline Total No. of trucks/day & 15 & 15 & 15 & 15 & 15 & 15 & 15 & 15 & 150 & \\
\hline Sampled vol/day $\left(\mathrm{m}^{3}\right)$ & 135 & 135 & 135 & 135 & 135 & 135 & 135 & 135 & 1350 & \\
\hline
\end{tabular}

\section{Foreign Material Load Distribution}

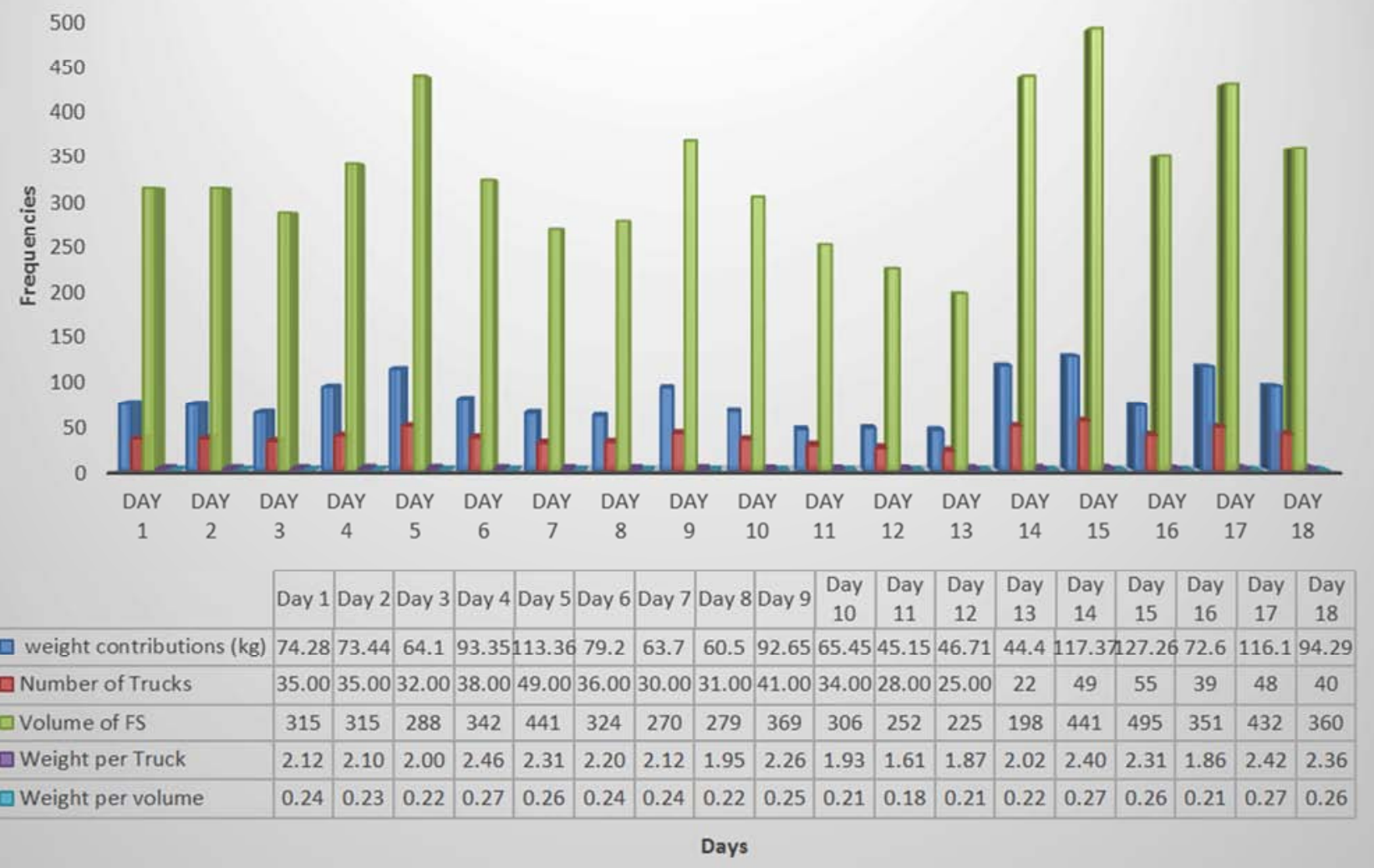

Figure 2. Foreign material load distributions in the faecal sludge of Greater Accra Region of Ghana. 


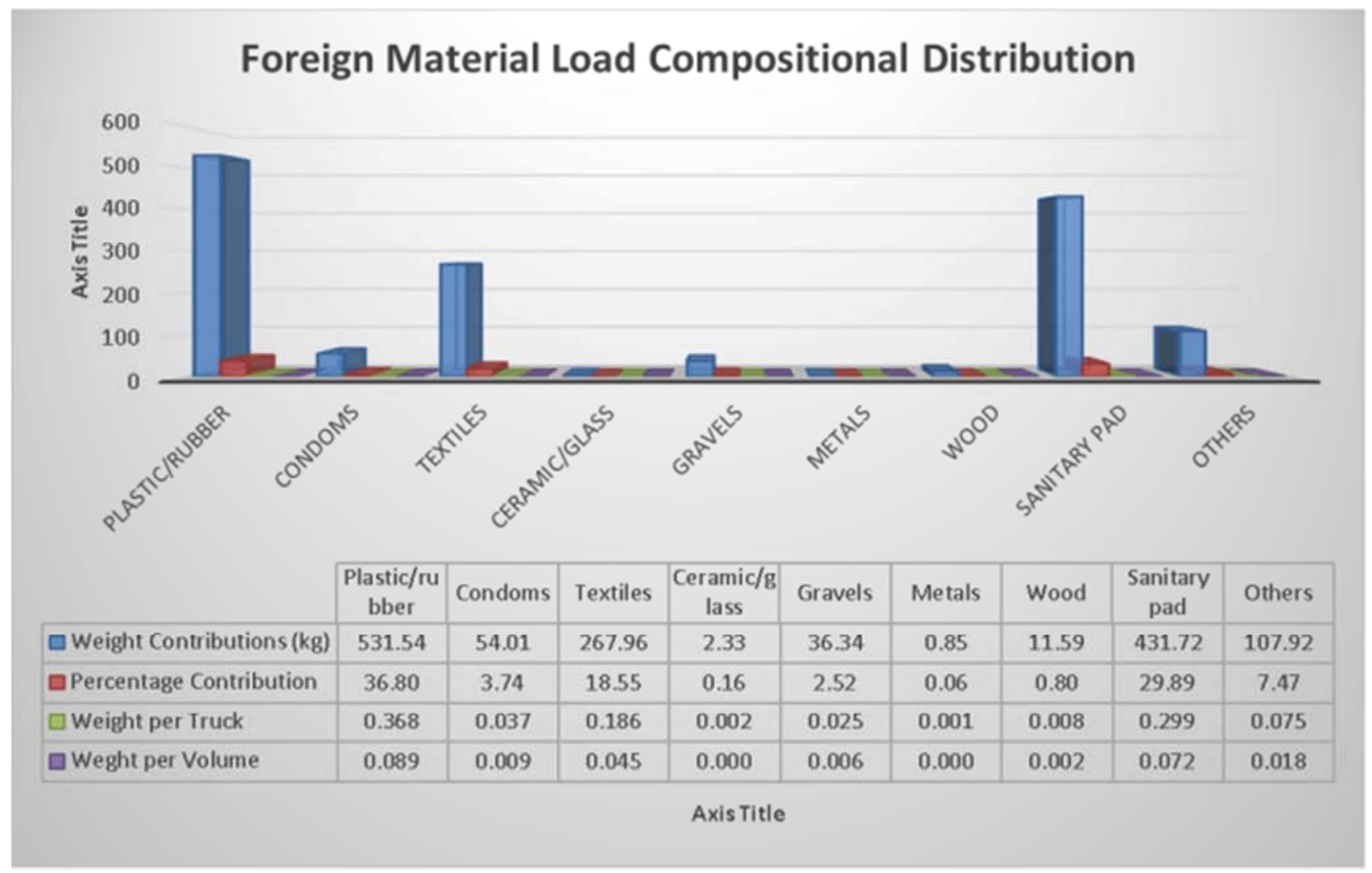

Figure 3. Foreign material load compositional distributions in the faecal sludge of Greater Accra Region of Ghana.

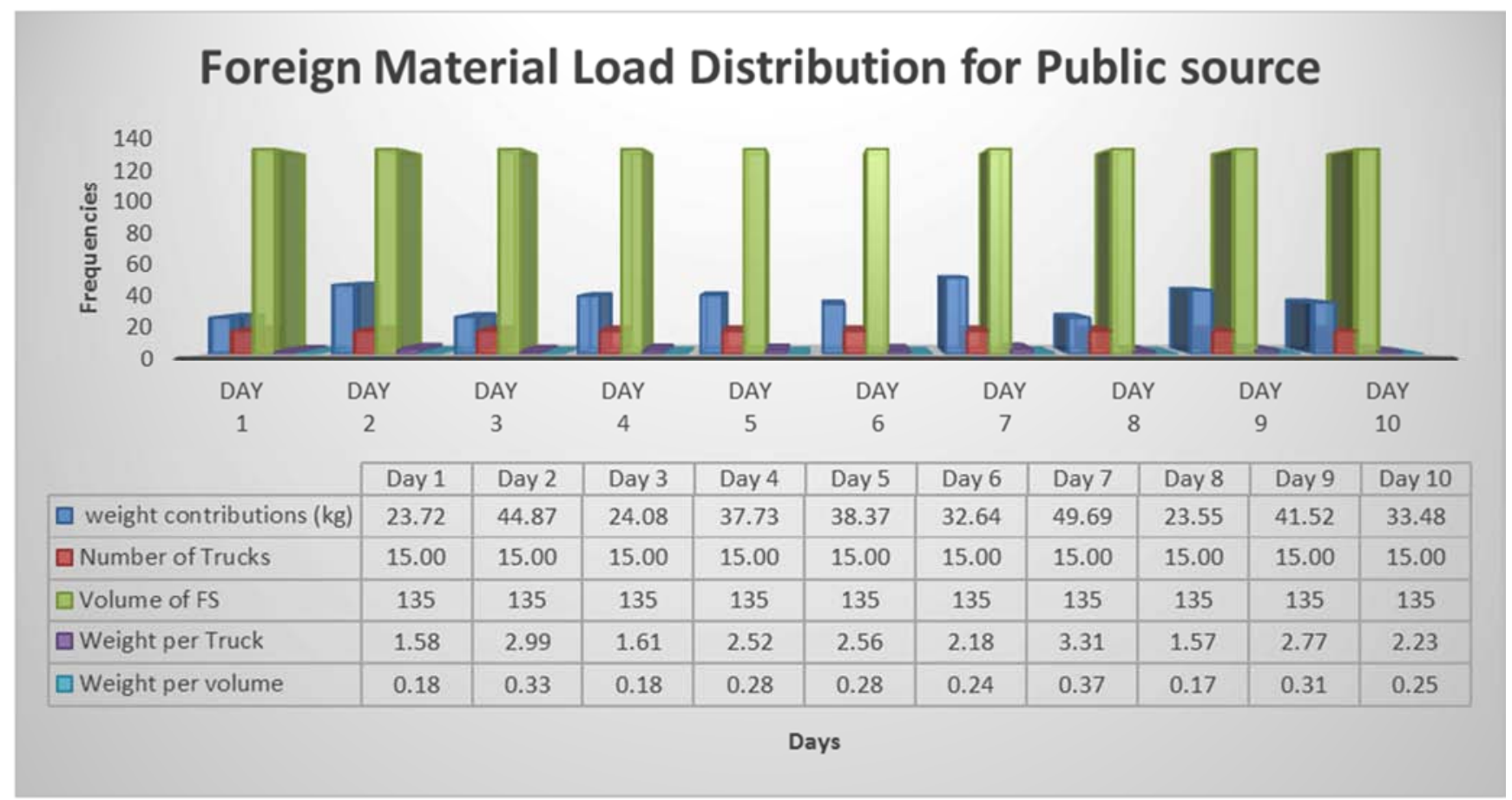

Figure 4. Foreign material load distributions in the faecal sludge from public toilet facilities. 


\section{Foreign Material Load Distribution for Private source}

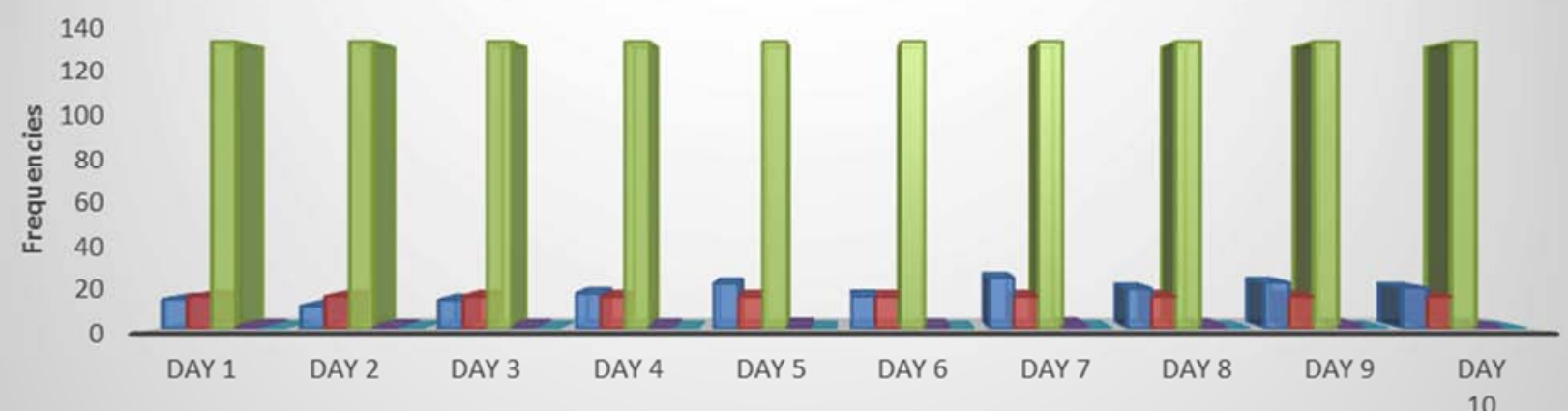

\begin{tabular}{|c|c|c|c|c|c|c|c|c|c|c|}
\hline & Day 1 & Day 2 & Day 3 & Day 4 & Day 5 & Day 6 & Day 7 & Day 8 & Day 9 & Day 10 \\
\hline$\square$ weight contributions ( $\mathrm{kg}$ ) & 13.69 & 10.52 & 13.27 & 16.38 & 21.02 & 15.17 & 23.86 & 18.64 & 21.5 & 18.92 \\
\hline$\square$ Number of Trucks & 15.00 & 15.00 & 15.00 & 15.00 & 15.00 & 15.00 & 15.00 & 15.00 & 15.00 & 15.00 \\
\hline$\square$ Volume of FS & 135 & 135 & 135 & 135 & 135 & 135 & 135 & 135 & 135 & 135 \\
\hline$\square$ Weight per Truck & 0.91 & 0.70 & 0.88 & 1.09 & 1.40 & 1.01 & 1.59 & 1.24 & 1.43 & 1.26 \\
\hline$\square$ Weight per volume & 0.10 & 0.08 & 0.10 & 0.12 & 0.16 & 0.11 & 0.18 & 0.14 & 0.16 & 0.14 \\
\hline
\end{tabular}

Figure 5. Foreign material load distributions in the faecal sludge from private toilet facilities.

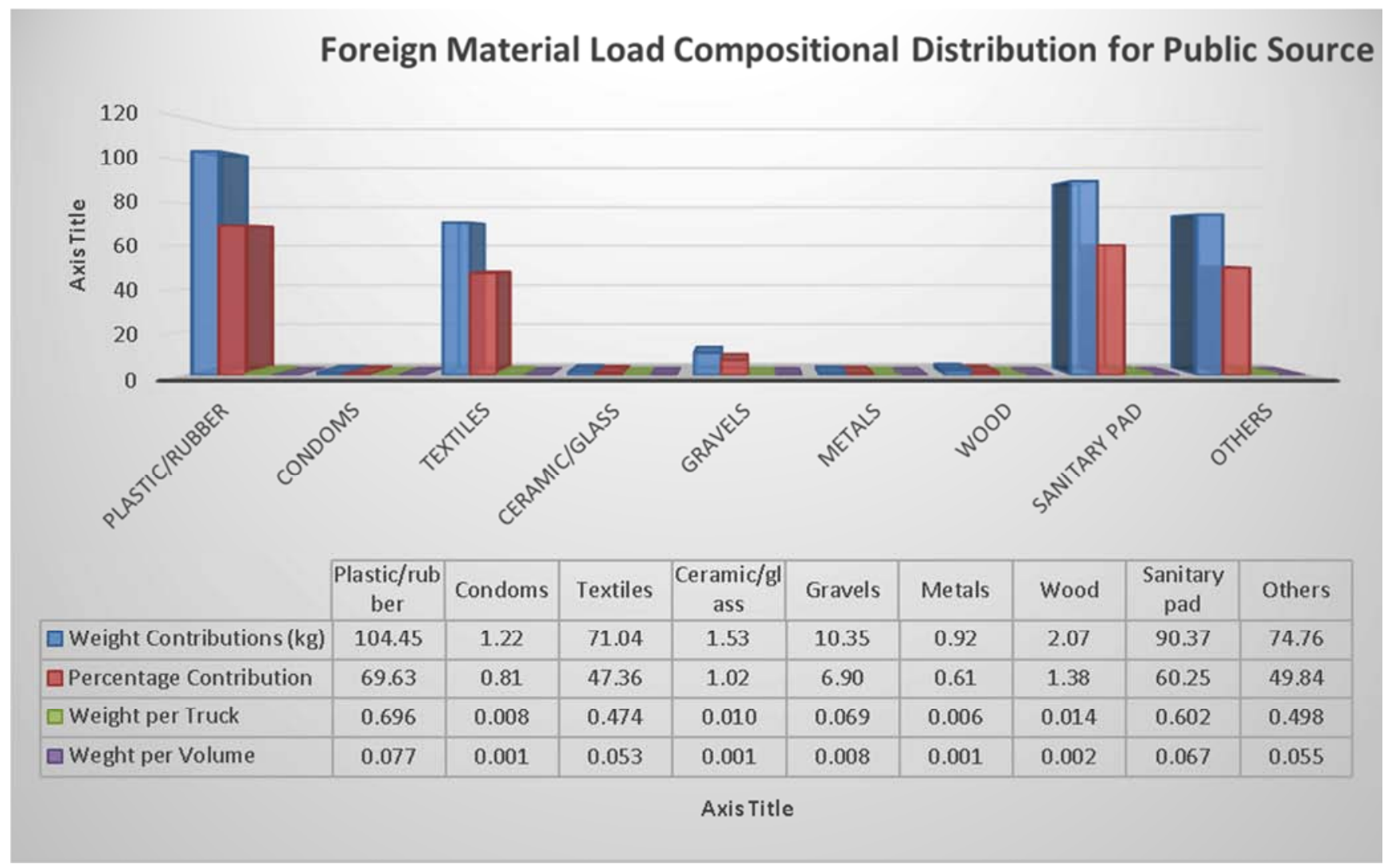

Figure 6. Foreign material load compositional distributions in the faecal sludge from public toilet facilities. 


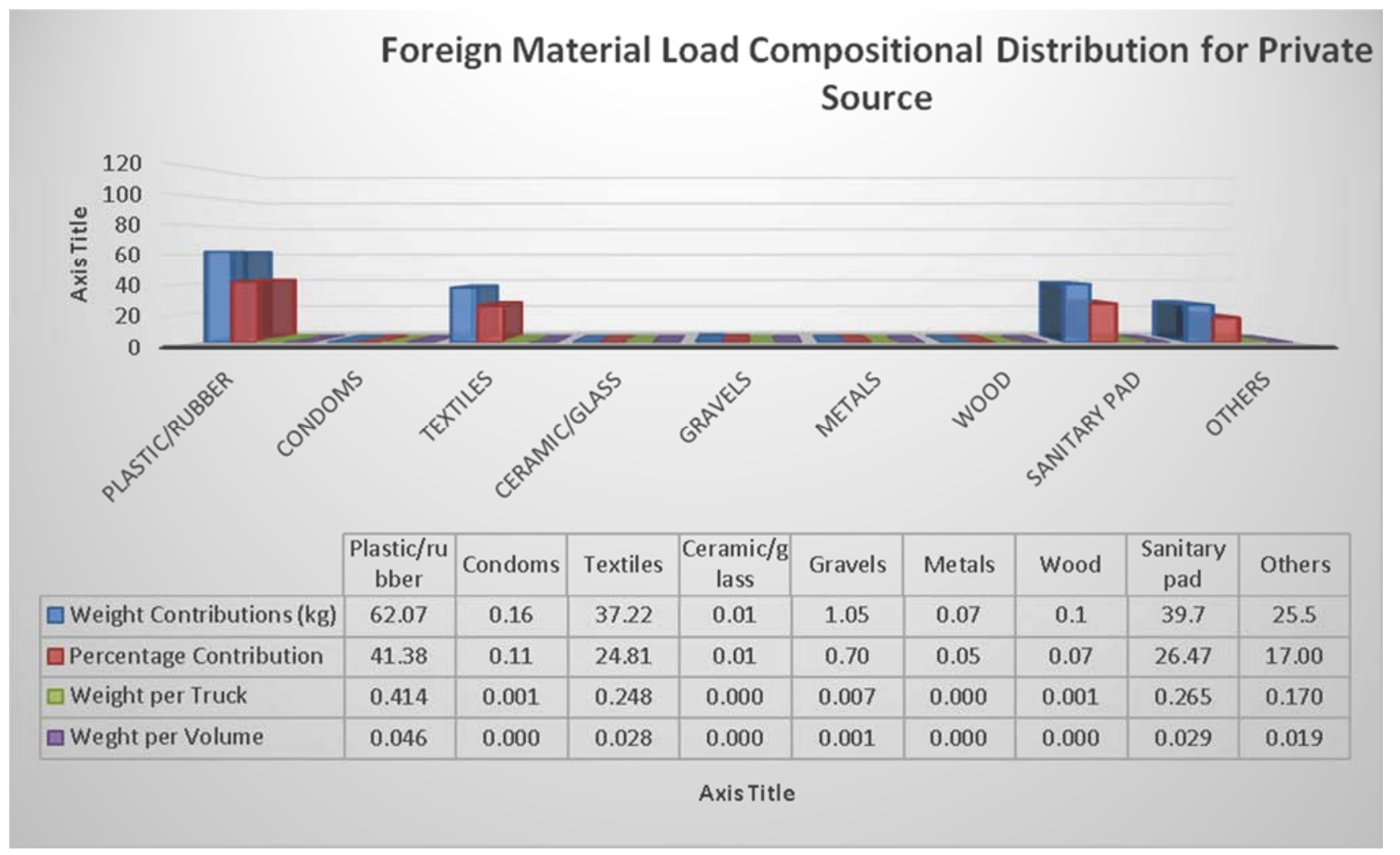

Figure 7. Foreign material load compositional distributions in the faecal sludge from private toilet facilities.

\section{Discussions}

The findings of the study are presented in table 1 and 2 as well as figure 2,3,4,5 and 6. From table 1, the total volume of faecal sludge in consideration is $6003 \mathrm{~m}^{3}$ that is about 667 cesspit trucks and the overall weight of foreign materials in the sampled faecal sludge was noted to be $1,444.32 \mathrm{~kg}$. The results indicate that the foreign material load in the faecal sludge in the Greater Accra region is about $0.24 \mathrm{~kg} / \mathrm{m}^{3}$ and this indicates that each truck contains an equivalent foreign material of about $2.17 \mathrm{~kg} / \mathrm{truck}$.

The daily foreign material load distribution is shown in figure 1 , and the minimum truck received over the period was noted to be 22 trucks on the $13^{\text {th }}$ day and 55 trucks being the highest recorded on the $15^{\text {th }}$ day. The minimum foreign material load per truck was $1.95 \mathrm{~kg} /$ truck and the maximum recorded was $2.46 \mathrm{~kg} /$ truck against an average load of $2.17 \mathrm{~kg} /$ truck. Again, $0.18 \mathrm{~kg} / \mathrm{m}^{3}$ was seen to be the minimum load per volume of the faecal matter whiles $0.27 \mathrm{~kg} / \mathrm{m}^{3}$ was the maximum recorded against an average volumetric load of $0.24 \mathrm{~kg} / \mathrm{m}^{3}$. The high ratio of these load gives an idea of the herculean task that the Lavender Hill faecal treatment plant where the survey was conducted has to deal with on average; and this was realized to be about $82 \mathrm{~kg}$ of trash in an hour at the primary screening stage during the peak period of treatment.

Plastics/Rubbers (36.80\%) formed the highest proportion of the overall foreign material composition of the FS sampled for the study with an equivalent weight of about $531.54 \mathrm{~kg}$ of the total weight (Figure 3). The sanitary component recorded a total weight of about 431.72 an equivalent contribution of about $29.89 \%$ and it is the second highest contributor. The third highest contributor in terms of both weight and percentage is the textiles/fabrics category. The textiles/fabrics recorded a percentage of $18.55 \%$ of the total foreign material composition in the sample by contributing an equivalent weight of $267.96 \mathrm{~kg}$ of the total weight obtained.

Several factors can account for the occurrence of this material in the faecal sludge as well as its high weight. Many people in the municipalities where these FS were suctioned may live under the low-income bracket and so may not be able to afford a sanitary tissue paper for cleaning up after visiting the loo and so may resort to using these fabrics after which they dump it in the toilet bowls or the pit latrines. Again, it is possible that these materials are found in faecal sludge because in many urban slams and rural communities where the FS was suctioned, pit latrines may have been used by some mothers as a means of disposing off their new born babies, in other to escape public ridicule. These mothers may normally wrap their unwanted day-old babies with cloth and drop them in the pit latrines; there have been several media reports of such incidences in rural and urban slam communities.

Next to the textiles/fabrics was seen to be the 'Others' category (7.47\%) which included cotton wool, broom sticks, paper wrappers, cartons, feotus, etc. with an equivalent weight of about $107.92 \mathrm{~kg}$. This category is mostly materials that are usually intertwined with other materials and normally very difficult to separate into their individual components. During the study period only one feotus was identified 
however, several feotus have been isolated since the inception of the plant with average weight between 2.2 $3.5 \mathrm{~kg}$ and mostly found in trucks from the public toilets. It is a clear indication that, people are still engaging in illegal abortions and are resorting to the public toilets which are rather supposed to be sanitation solution as point of dumping their unwanted babies.

Condoms formed $3.74 \%$ of the total content of foreign materials in FS and also weighed $54.01 \mathrm{~kg}$ with an average per unit weight of about $0.003 \mathrm{~kg}(3 \mathrm{~g})$. The quantity of condoms found in the sampled FS was estimated to be approximately 18,003 pieces but due to its light weight it recorded the fourth highest in terms of weight. Though they are not to be disposed in toilets and pit latrines, the presence of this huge number of condoms in the sampled FS suggest that people still continue to disposed it together with tissues and other sanitary cleaning materials into toilet bowls in households and pit latrines after use. Gravels recorded about $36.34 \mathrm{~kg}$ per the total weight of the foreign material observed representing a percentage by weight of about $2.52 \%$. Wood $(0.80 \%)$, Glass $(0.16 \%)$ and Metals $(0.06 \%)$ formed $11.59 \mathrm{~kg}$, $2.33 \mathrm{~kg}$ and $0.85 \mathrm{~kg}$ respectively of the overall weight of the foreign material composition of the FS sampled.

The presence of all these non-biodegradable solid waste content in sampled faecal sludge can be traced to pit latrines which form the main means of disposal of solid waste especially in urban slam settlements in municipalities. The presence of some of the solid waste like sanitary, papers, rubbers has been highlighted by some research works $[7,14]$ and its characteristic component for some few ones noted by the works of Ahamadi et al., [15] on Kampala pit latrine faecal sludge. Our work gives an extensive investigation of the characteristics component of the foreign materials (solid waste) in the faecal sludge as in consonance with [8, 15-16]. The order of the load of the foreign materials were noted to be in the order of Plastics/Rubbers $>$ Sanitary pads $>$ Textiles/Fabrics $>$ Others $>$ Condoms $>$ Gravels $>$ Wood $>$ Glass $>$ Metals.

This comprehensive data reporting on the previous paragraphs is a composite representation of the faecal sludge (mixture from both public and private toilet). And to be able to assess the load based on the source (either public or private) from where the faecal sludge is being brought from, the assessment was further characterised in details based on public and private. From table 2, the total volume of faecal sludge considered was $1350 \mathrm{~m}^{3}$ for the public toilets while that of the private toilet was also $1350 \mathrm{~m}^{3}$. These volumes were representation of about 150 cesspit trucks for each with an overall weight of foreign materials in the sampled faecal sludge being $349.65 \mathrm{~kg}$ and $172.97 \mathrm{~kg}$ respectively. The public toilet source was seen to have a foreign material load of about $0.13 \mathrm{~kg} / \mathrm{m}^{3}$ and $0.26 \mathrm{~kg} / \mathrm{m}^{3}$ for the private source. The average foreign material load per truck recorded was $2.33 \mathrm{~kg} /$ truck for the public toilet and $1.15 \mathrm{~kg} /$ truck representing the private toilets. The load distributions as well as the compositional distributions were higher in the public toilets (figure 3 and 4 ) than the private toilets (figure 4 and
5). The order in the compositional trend in terms of percentage contributions of the components noted for the composite sample was not different from the ones seen in the separate sources (public and private) even though the frequencies vary (figure 2, 6 and 7). However, some of the compositions (Wood, Metals and Glass) were not present in most cases and recorded zero percentage contributions especially in the private toilets (figure 7).

The further characterisation done on the public and private toilets in the area of the foreign material load assessment has revealed that, most of the loads especially plastics/rubbers, condoms, textiles, sanitary pads and gravels comes from the public toilets. This implies that, the more trucks received from the public toilets the more the pressure would be on the process of treatment especially at the mechanical screening point and the more likely of escape of some of the lighter ones like condoms and rubbers into the reservoirs with high potential of clogging of pumps in use.

\section{Conclusion}

Faecal sludge is another waste material that possesses many potentials of being a resource after processing. This notwithstanding its content is replete with other foreign and non-biodegradable components aside its physicochemical properties. In this survey, materials such as fabric, glass, stones, textiles, condoms, feotus, wallet, ID cards, mobile phones, local currency (money) and metals were found to be significant part of faecal sludge suctioned and transported for treatment. Consideration should therefore be given to any design of such waste treatment plant to take care of the foreign material component to make its treatment efficient.

Education on the proper use of public and domestic latrines and better disposal practices is also relevant to help improve on the disposal practices of members of communities where the latrines are being used as another secluded area of disposing refuse. Designers of public latrines in particular can also consider a redesign of these latrines to make it impossible for it to be used as a dumping pit for domestic waste.

Personnel who usually, visit the public toilets should be mindful of their belongings as several personal belongings like the mobile phones, ID cards, wallet, money, Memory chips, SIM cards, among others were noted and were typical characteristic component of the FS from the public toilets rather than the domestic toilets. Some of these items that have the potential to be reused like the money, memory chips or mobile phones could potential be a source of spread for disease like cholera and diarrhea as the FS contains a lot of pathogenic bacteria.

\section{Acknowledgements}

The authors would like to extend their profound gratitude to Sewerage Systems Ghana Ltd., the Executive Chairman (EC) of the Jospong group of companies (JGC), as well as the Board and Management of Sewerage Systems Ghana ltd. 


\section{References}

[1] UNICEF \& World Health Organization (2008), Progress on drinking water and sanitation special focus on sanitation, Geneva Switzerland.

[2] UNICEF \& World Health Organization (2012). Progress on drinking water and sanitation: future prospects for food and feed security. 2012 update; 2012. p. 66.van Huis A, Van Itterbeeck J, Klunder H Mertens E, Halloran A, Muir G, et al. Edibleinsects: Rome: FAO; 2013. p. 201

[3] Daniele (2016), As Rio bay waters show; we badly need innovation in treating human wastes Tufts University, Retrieved from [http//theconversation.com/profiles/danielelantagne-287703].

[4] UNEP/GEF/KALMAR Högskola, Invemar, (2006), Global International Water Assessment(GIWA), Caribbean Sea/Colombia \& Venezuela, Central America \& Mexico GIWA Regional Assessment 3b, 3c, Kalmar Sweden.

[5] Awuah E. and Abrokwa K. A. 33 $3^{\text {rd }}$ WEDC International Conference, Accra Ghana 2008; Access to sanitation and safe water: Global partnership and local action. Performance evaluation of the UASB Sewage treatment plant at James Town (Mudor) Accra.

[6] Doulaye Koné (2012), Fecal Sludge Management in Africa and Asia. Bill and Melinda Gates Foundation (BMGF) Retrivedfrom[https://saniblog.org/wp-content/2012/12/10country-FSM-final-Report_september-12-1-2-copy.pdf]

[7] Doku A. I. (2003) The potential for the use of upflow anaerobic sludge blanket (UASB) reactor for the treatment of faecal sludges in Ghana (BSc (Kumasi), MSc (Leeds), MASc (Toronto), $\mathrm{PhD}$ (Leeds).

[8] UNICEF (2016), Assessment of waste water treatment plants in Ghana by civil engineering Department KNUST.

[9] Brook L. (2012), Rapid Evidence Review Littering Behaviour and anti-litter Policies, Zero waste Scotland commission report. Scotland http://www.zerowastescotland.org.uk/sites/files/zws/

[10] Boot N. L. D. AND SCOTT R. E. (2008), Faecal sludge management in Accra, Ghana: strengthening Links in the chain. In: Access to sanitation and safe water: Global partnerships and local actions, 33rd we Dc international conference, Accra, Ghana.

[11] Cofie O, Kone D, Rothenberger S, Moser D, Zubruegg C. (2009), Co-composting of faecal and organic solid waste for agriculture: process dynamics. Water Res2009; 43 (18): 466575 .

[12] Kuffour A. R, Awuah E, Anyemedu F. O. K, Strauss M, Koné D, Cofie O. (2009), Effect of using different particle sizes of sand as filter media for dewatering faecal sludge. Desalination; 248 (1-3): 308-14.

[13] Owusu, C. (2013), Public - private partnership in faecal sludge collection and treatment in Ashanti region of Ghana Unpublished thesis (Msc.) Kwame Nkrumah University of Science and Technology, Ghana

[14] Strande A. L, Ronteltap M, Brdjanovic D. (2014), Faecal Sludge Management; Systems Approach For Implementation And Operation. Published by IWA Publishing Alliance House 12 Caxton Street London SW1H 0QS, UK.

[15] Ahamada Zziwa, Isa Kabenge, Henry Kayondo, Yvonne Lugali, Robert K. Kambugu, Joshua Wanyama (2016) Fractional Content Of Non-Feacal Matter And Its Contribution To Filling Rates of Pit Latrines in Kampala Slums Global Journal of Engineering Science and Research Management http: // www.gjesrm.com

[16] UNICEF-Ghana (2015). Water, sanitation and hygiene, the case for support, (December), 1-14.

[17] UNICEF, Uni, Noorani. (2016). Strategy for Water, Sanitation and Hygiene. Retrieved from https://www.unicef.org/wash/files/UNICEF_strategy_for_WA SH_2016_2030.PDF 